Available online:

http://journal.imla.or.id/index.php/arabi

IMLA

Arabi : Journal of Arabic Studies, 5 (2), 2020, 177-190

DOI: http://dx.doi.org/10.24865/ajas.v5i2.293

\title{
HIGHER ORDER THINKING SKILLS DALAM KOMPETENSI DASAR BAHASA ARAB
}

\author{
Ahmad Muradi, Faisal Mubarak, Ridha Darmawaty, Arif Rahman Hakim \\ Universitas Islam Negeri Antasari Banjarmasin, Indonesia \\ E-mail : ahmadmuradi@uin-antasari.ac.id
}

\begin{abstract}
Learning Arabic is more dominant as a skill than a Science. The learners' goals are able to use Arabic both spoken and written well and correctly. While HOTS is more dominant in requiring learners to think integrally. Therefore, it is important to consider the extent to which the Ministerial Regulation accommodates HOTS through a study of the basic competence of Arabic contained in it. This study is a literature review of the basic competence of Arabic in the Decree of the Minister of Religion (KMA) number 183 in 2019 in HOTS perspective. The object of this study is the basic competence of Arabic in KMA 183 in 2019. The result shows the basic competence of Arabic in KMA 183 in 2019 to accommodate the ability in higher order thinking such as problem solving, critical thinking, and reasoning. While the Basic Competence in KMA didn't achieve creative thinking and decision making.
\end{abstract}

Keywords: HOTS, basic competence, Arabic

\begin{abstract}
Abstrak
Pembelajaran bahasa Arab lebih dominan sebagai keterampilan daripada ilmu pengetahuan. Karena tujuannya adalah pembelajar mampu menggunakan bahasa Arab baik lisan maupun tertulis dengan baik dan benar. Sementara HOTS lebih dominan mengharuskan pembelajar berpikir secara integralistik untuk memperoleh pengetahuan yang meliputi tingkat berpikir analitis, sintesis, dan evaluatif. Oleh karena itu penting mengkaji KMA 183 tahun 2019 yaitu sejauhmana KMA ini mengakomodasi HOTS melalui kajian terhadap kompetensi dasar Bahasa Arab yang ada di dalamnya. Penelitian ini merupakan kajian literatur terhadap Kompetensi dasar bahasa Arab dalam KMA 183 tahun 2019 dalam perspektif HOTS. Objek penelitian ini adalah Kompetensi dasar bahasa Arab dalam KMA 183 tahun 2019. Metode pengumpulan data yang dipakai dalam penelitian ini adalah dokumentasi. Hasil penelitian menunjukkan bahwa kompetensi dasar bahasa Arab dalam KMA 183 tahun 2019 mengakomodasi kemampuan berpikir tingkat tinggi seperti problem solving, critical thinking, dan reasoning. Sementara KD dalam KMA tersebut tidak mencapai creative thinking dan decision making.
\end{abstract}

Kata Kunci: HOTS, kompetensi dasar, bahasa Arab 


\section{Arabi : Journal of Arabic Studies}

\section{Pendahuluan}

Acuan dalam setiap pembelajaran adalah kompetensi dasar (KD) pembelajaran. Sebab penjabaran kegiatan pembelajaran selalu mengacu pada KD ini. Dari KD ini diturunkan menjadi tujuan pembelajaran dan indikator keberhasilan pembelajaran. Jadi, kompetensi dasar ini merupakan aspek penting yang harus diperhatikan setiap guru. Maka dengan pemahaman yang baik terhadap KD tersebut akan mudah bagi guru menerapkannya. (Albantani, 2015) guru yang seperti ini dapat disebut dengan guru yang professional. (Direktorat Jenderal Guru dan Tenaga Kependidikan Kementerian Pendidikan dan Kebudayaan, 2019) Oleh karena itu mau tidak mau guru dituntut untuk terus mengembangkan diri baik secara pribadi maupun dalam suatu organisasi profesi. (Muradi, 2016)

Guru merupakan orang yang memfasilitasi pembelajaran bagi pembelajar harus memiliki kemampuan dalam menjabarkan rumusan KD yang sudah ditetapkan pemerintah. Karena itu, guru hendaknya dapat menjabarkan rumusan tersebut ke dalam ranah kompetensi berupa kemampuan kognitif, efektif, dan psikomotorik atau yang disebut dengan taksonomi Bloom (1956). (R. Collins , 2014) Ketiga ranah tersebut memiliki penjabaran dari level rendah sampai level tinggi. Maka, penjabaran level ini sangat ditentukan oleh siapa yang menjadi sobjek pembelajaran dan level berapa mereka dapat mencapainya.

Berdasarkan kebijakan Pemerintah Indonesia melalui Direktorat Jenderal Guru dan Tenaga Kependidikan (Ditjen GTK) pada tahun 2018 tentang penguatan pendidikan karakter yang diintegrasikan dengan pembelajaran yang mengarah kepada keterampilan Berpikir Tingkat Tinggi atau Higher Order Thinking Skill, maka penjabaran KD dengan komponen ranah taksonomi Bloom menuju kepada orientasi yang telah diberlakukan oleh pemerintah. Sehingga semua pembelajaran harus mengacu kepada kebijakan tersebut.

Berdasarkan hasil studi Programme for Internastional Student Assesment bahwa kemampuan siswa Indonesia masih belum menggembirakan. Yaitu dalam kemampuan membaca, siswa Indonesia hanya meraih skor rata-rata 371 dari skor OECD 487. Skor rata-rata matematika diraih 379 dari skor rata-rata OECD 487 dan skor sains diraih 398 dari skor OECD 489. (https://www.oecd.org/pisa/, 2019). Juga berdasarkan laporan Kepala Badan Penelitian dan Pengembangan Totok Suprayitno bahwa masih banyak guru menganggap bahwa konsep ajar HOTS ini sulit diterapkan baik bagi guru maupun bagi peserta didik. Namun kata Suprayitno bahwa HOTS itu membawa guru lebih kreatif dalam rangka pembelajaran yang mengandalkan nalar dan memecahkan soal bagi anak-anak. (https:/www.republika.co.id/, 2020) Dari penjelasan di atas, artinya penting memahami konsep HOTS dan penerapannya dalam penjabaran KD dalam setiap pembelajaran.

Kajian tentang HOTS dikaitkan dengan pembelajaran sudah banyak dilakukan. Sejak tahun 2013 hingga 2019 paling tidak terdapat duabelas artikel tentang HOTS ini. Dapat penulis klasifikasikan menjadi 3 bagian yaitu 1) artikel tentang pemahaman HOTS dalam pengajaran, 2) artikel tentang Uji coba metode, model dan media pembelajaran untuk mencapai HOTS, dan 3) artikel tentang penerapan dan pengembangan.

Yang termasuk kategori pertama adalah artikel R. Collin (2014), Rahmawati (2018), Ainin (2018) dan Mustain (2019) Dalam artikel R. Collins disebutkan bahwa penting bagi guru mengetahui pentingnya mengajarkan keterampilan berpikir tingkat tinggi untuk mempersiapkan pria dan wanita muda untuk hidup di abad ke-21. Collins (2014) menyebutkan ada 5 tahapan yang dapat dilakukan guru untuk mecapai keterampilan berpikir mengajar dengan cara yang terstruktur yaitu 1) mengajarkan bahasa dan konsep berpikir tingkat tinggi, 2) Meningkatkan keterampilan berpikir tingkat tinggi dengan cara berdiskusi, 3) menjelaskan konsep dasar secara sederhana, 4) adanya contoh dan model, dan 5) selalu memotivasi peserta didik dalam berpikir tingkat tinggi.

Yang termasuk kategori kedua seperti Yuniawati (2013), M. Hugerat dan N. Kortam (2014) dan Chinedu, Olabiyi, \& Kamin, Y. (2015). Artikel M. Hugerat dan N. Kortam (2014) mengatakan 
bahwa bahwa dalam pengembangan HOTS harus didukung metode pembelajaran sehingga para peserta didik dapat bersikap positif, baik secara emosional maupun kognitif.

Sementara yang termasuk kategori ketiga adalah Abdullah, Abidin, \& Ali (2015), Hayikaleng, Nair, \& Krishnasamy (2016), Alsowat (2016), Margana dan Agus Widyantoro (2017) dan Saido, Siraj, Nordin, \& Al-Amedy (2018). Margana dan Agus Widyantoro (2017) dalam artikelnya mengatakan bahwa pengembangan buku teks bahasa Inggris melalui teori HOTS dapat membangun kreativitas dan meningkatkan keterampilan berpikir kritis siswa dalam memperoleh bahasa target.

Dari tiga contoh artikel yang mewakili duabelas artikel yang terkait dengan kajian HOTS bisa dikatakan bahwa tulisan ini berbeda, yaitu artikel ini fokus kepada kajian kompetensi Dasar Bahasa Arab berdasarkan KMA 183 tahun 2019 disorot aspek HOTSnya.

\section{Metode}

Berdasarkan pendahuluan di atas, metode penelitian yang digunakan dalam penulisan ini adalah deskripstif kualitatif yang bertujuan mengkaji suatu objek secara mendalam. Dalam mengungkapkan hasil penelitian, penulis membuat narasi sesuai informasi yang diperoleh setelah dilakukan pengolahan dan analisis yang maksimal. (Moleong, 2010). Objek penelitian ini adalah Kompetensi dasar bahasa Arab dalam KMA 183 tahun 2019. Yang menjadi data dalam penulisan ini adalah dokumentasi. (Sugiyono, 2016) Dokumen dalam penulisan ini adalah KMA 183 tahun 2019 yang sekaligus menjadi sumber data. Proses analisis data dalam penelitian ini adalah: (1) transcript, yaitu menulis semua data yang diperoleh berdasarkan telaah terhadap KMA 183 tahun 2019 dan (2) verifikasi, yaitu membuat simpulan dari hasil kajian.

\section{Higher Order Thinking Skill}

Dalam ranah kognitif terdapat keterampilan berpikir. Keterampilan ini merupakan suatu yang bersifat abstrak yang kemudian direalisasikan dalam bentuk nyata berupa langkah-langkah konkrit dalam proses berpikir. Sebagai contoh keterampilan berpikir adalah mengambil sebuah simpulan. Proses dari pengambilan simpulan adalah dari kemampuan menghubungkan berbagai petunjuk dan fakta atau juga informasi dengan informasi sebelumnya yang telah dimiliki untuk mengambil suatu perkiraan sebagai simpulan akhir. Langkah-langkah dalam pembelajaran keterampilan berpikir menarik kesimpulan ini adalah sebagai berikut: (a) membuat daftar pertanyaan yang mengarah kepada simpulan yang akan dibuat, (b) membuat daftar fakta yang telah diketahui, (c) membuat daftar informasi yang telah diketahui yang berkaitan dengan penarikan simpulan dan (d) membuat rumusan perkiraan hasil akhir.

Keterampilan berpikir memiliki tiga termenologi, yaitu berpikir tingkat tinggi, berpikir kompleks dan berpikir kritis. Berpikir tingkat tinggi adalah proses kognitif yang terjadi dalam memory pendek. Berpikir kompleks adalah proses kognitif yang terkait denga hal-hal yang banyak dan berpikir kritis adalah proses kognitif yang memfokuskan diri pada satu titik. Dalam tataran berpikir tingkat tinggi menurut Heong, dkk. (2011) kemampuan yang dimaksud adalah berpikir secara luas dalam rangka mendapatkan tantangan yang lebih kompleks.

Kemampuan berpikir tingkat tinggi ini mengharuskan peserta didik untuk menggunakan pengetahuan baru dan sebelumnya serta mengolah informasi baru dalam rangka mendapatkan simpulan akhir sebagai jawaban yang terkait dengan situasi baru. Dalam bahasa lain, berpikir tingkat tinggi adalah kemampuan mengolah informasi dengan caranya tersendiri yang bukan hafalan fakta atau hanya mengulang dari informasi yang diperoleh sebelumnya. Menurut Herman (2007), kemampuan berpikir tingkat tinggi merupakan proses olah mental dengan memaksimalkan kemampuan berpikir secara komprehensif yang pada akhirnya menemukan suatu tujuan yang diinginkan.

Dari berbagai pendapat di atas, dapat penulis simpulkan bahwa kemampuan berpikir tingkat tinggi adalah proses kognitif yang di dalamnya aktivitas olah mental dari proses menghubungkan 


\section{Arabi : Journal of Arabic Studies}

bagian-bagian, memahami informasi baru berdasarkan pemahaman dan informasi lama yang telah dimiliki, kemudian membuat suatu perkiraan sebagai simpulan akhir dari tujuan yang diinginkan. Dari simpulan akhir itu didapat pemecahan terhadap problem yang dihadapi sesuai situasi yang baru.

Dalam catatan Krathwohl dan Anderson (2001), Bloom telah letakkan pondasi dasar dalam taksonominya terkait berpikir tingkat tinggi yaitu C4 analisis, C5 evaluasi dan C6 mencipta. Kriteria dalam mengukur kemampuan berpikir tingkat tinggi yaitu sebagai berikut. (1) menelaah data-data yang merupakan satuan dari bagian-bagian kecil, kemudian menemukan hubungan bagian-bagian kecil tersebut dari aspek penyebab dan akibat, (2) memberikan penilaian berdasatkan standar-standar terhadap pemecahan masalah, memberikan masukan dan cara-cara yang dilakukan guna melihat sejauh mana aktivitas dan manfaatnya, (3) mencipta, maksudnya adalah berkreasi membuat terobosan yang bersumber dari permasalahan yang ada dan kemudian menemukan pemecahannya. Dari situ dibuat hubungan-hubungan antar unsur hingga terwujud suatu struktur baru. Cara ini dapat digunakan dalam berbagai bidang, misalnya sains dan fenomena sosial. Dalam bidang sains dan fenomenal sosial, mencipta suatu hal yang tidak asing. Terciptanya suatu produk berasal dari munculnya kebutuhan manusia terhadap suatu barang yang kemudian dari kebutuhan manusia itu direalisasikan dalam bentuk barang. Proses ini tentunya melibatkan penelitian-penelitian terhadap unsur-unsur sains di dalamnya berdasarkan fenomena sosial yang terjadi di tengah masyarakat.

Pondasi dasar dalam ranah pendidikan yang telah diletakkan Bloom sangat bermanfaat yaitu sebagai pedoman dalam menetapkan tujuan pendidikan, pembuatan bahan tes, kurikulum di semua lembaga pendidikan di dunia. Pondasi ini juga memudahkan para pendidik dalam mewujudkan tujuan pendidikan dari perencanaan, pelaksanaan dan evaluasi.

Perkembangan pengetahuan dalam bidang pendidikan yang terjadi membuat Lorin W. Anderson yang merupakan salah seorang murid Bloom bersama rekannya merivisi taksonomi Bloom. Tujuan revisi ini adalah terciptanya system berpikir yang lebih aktif dan akurat terkait dengan tujuan pendidikan dalam ranah kognitif. Hasil revisi ini telah dipublikasikan pada tahun 2001 dalam karya mereka yang judul "A Taxonomy for Learning, Teaching, and Assesing: Arevision of Bloom's Taxonomy of Educational Objectives"

Di sini dapat disampaikan beberapa hasil revis yang telah dilakukan yaitu (1) perubahan kata kunci dan nama dari kategori kata benda menjadi kata kerja, (2) pengurutan dari kategori terendah ke kategori tertinggi secara hierarki, (3) integrasi istilah berpikir analisis dan sintesis menjadi istilah analisis, (4) memasukkan kategori baru yaitu creating sebagai tingkat tertinggi dalam tujuan pendidikan. Dari hasil revisi ini tidak mengurangi enam kategori karena adanya integrasi analisis dan sintesis menjadi analisis namun ditambah dengan kreasi.

Revisi yang dilakukan Krathwohl dan Anderson (2001) dapat dibagi menjadi dua dimensi, yaitu dimensi pengetahun dan dimensi kognitif. Dimensi pengetahuan adalah yang mencakup pengetahuan faktual, konseptual, prosedural dan metakognitif. Sedang dimensi kognitif mencakup enam aspek yaitu mengingat, memahami, menerapkan, menganalisis, menilai dan mengkreasikan.

Dari ranah taksonomi Bloom yang kemudian direvisi oleh Krathwohl dan Anderson berfokus pada aktivitas akal. Aktivitas akal disebut dengan berpikir. Aktivitas ini memerlukan kecakapan yang perlu diasah. Sebab kecakapan berpikir membantu manusia dalam melakukan perubahan. Maksudnya adalah apa yang telah dilakukan manusia sebelumnya kemudian dilakukan evaluasi, maka dari situ akan melahirkan keputusan untuk bersikap dan perilaku baru bagi manusia. Hal ini merupakan akibat dari kecakapan berpikir. Oleh karena itu, kecakapan berpikir sangat perlu dipelajari dan diajarkan cara yang tepat bagi para peserta didik dalam mengikuti proses pendidikan.

Kecakapan berpikir menjadi poin penting bagi tujuan pendidikan, sebab kecakapan berpikir ini melatih para peserta didik untuk berpikir ilmiah. Berpikir ilmiah tidak hanya bersentuhan dengan aspek kognitif namun juga bersentuhan dengan aspek apektif dan psikomotorik. Karena, 
proses pembentukan sikap dan kriativitas bermuara pada sejauhmana pengetahuan dan pengalaman yang dialami oleh seseorang yang pada akhirnya membentuk kepribadian.

Secara fakta di lapangan bahwa pembelajaran di Indoensia lebih cenderung hanya aspek pengetahuan atau kognitif. Oleh karena itu, kurikulum tahun 2013 menetapkan bentuk pembelajaran melalui pendekatan ilmiah. Tahapan pendekatan ilmiah dalam kurikulum baru ini disebut dengan 5M, yaitu mengamati, menanya, mencoba, mengasosiasikan dan mengkomunikasikan. Dari 5M ini tercermin bahwa proses pembelajaran mengarahkan pada integrasi tiga ranah pendidikan. Ranah kognitif mengarahkan peserta didik untuk menggali pontensi pengetahuan dan cara berpikirnya. Ranah apektif mengarahkan peserta didik untuk membentuk sikap dan kepribadian yang baik sesuai fitrahnya sebagai manusia. Dan ranah psikomotorik mengarahkan peserta didik untuk mengembangkan kemampuan gerak dan kreativitasnya. Menurut Salahuddin dan Asroriyah (2019) kecakapan berpikir sangat menunjang proses pembelajaran dan sangat penting guna tercapainya tujuan pendidikan yang hakiki.

Melalui belajar kecakapan berpikir membantu para peserta didik berpikir secara luas dan mendalam sehingga mereka dapat menggapai kemampuan berpikir tingkat tinggi. Oleh karena itu, di samping proses pembelajaran, aspek penilaian hasil belajar juga diarahkan kepada HOTS. (Fanini, 2018) Maka kemudian yang perlu diperhatikan adalah kualitas instrument penilaian belajar. Jika instrument penilaian belajar berkualitas, gambaran kualitas proses belajar menjadi jelas. Namun jika instrument penilaian belajar belum mencerminkan tujuan pembelajaran terutama aspek kecakapan berpikir, hasilnya tidak dapat menjadi pijakan apakah proses pembelajaran berkualitas atau tidak. Dari sini, terdapat hubungan hasil penilaian dengan kemampuan berpikir peserta didik. (Widiansah dkk, 2019)

\section{HOTS dalam Pembelajaran Bahasa Arab}

HOTS adalah hasil kajian dan pengembangan dari konsep taksonomi Bloom (1956). Menurut catatan R. Collin (2014), Tujuan Bloom adalah mengarahkan proses pendidikan kepada tngkat berpikir yang lebih tinggi, seperti menganalisis dan mengevaluasi, dari pada terbatas pada mengingat fakta (hafalan). Aspek atau arah pembelajaran ditujukan kepada tiga ranah, yaitu kognitif, afektif dan psikomotorik.

Adapun HOTS ini termasuk dalam ranah kognitif dengan lambang C. Rincian ranah ini telah direvisi Anderson dan Krathwol seperti di bawah ini:

$\mathrm{C} 1$ = remembering, yaitu mengingat atau memanggil pengetahuan dari memori yang sudah disimpan atau dipelajari sebelumnya.

$\mathrm{C} 2=$ understanding, yaitu memahami pengetahuan yang sebelumnya telah diperoleh lalu dibuat konsep berdasarkan pemikiran sendiri.

$\mathrm{C} 3=$ applying, yaitu menerapkan apa yang sudah dipahami baik berupa konsep maupun materi dari pengetahuan sebelumnya.

$\mathrm{C} 4=$ analyzing, yaitu menghubungkan bagian-bagian yang terpisah pisah menjadi satu kesatuan.

$\mathrm{C} 5=$ evaluating, yaitu menilai berdasarkan rencana, menciptakan kriteria dan standar melalui rumusan pengumpulan, pengecekan dan kritik.

$\mathrm{C} 6=$ creating, yaitu membentuk pola dan model baru dari pemikiran atau pendapat sebelumnya melalui rencana, produk dan hasil. (Wilson, 2016)

Dari $6 \mathrm{C}$ di atas, dapat dibagi dua yaitu, C1-C3 merupakan bagian dari Lower Order Thinking Skills (LOTS) dan C4-C6 adalah bagian dari Higher Order Thinking Skills (HOTS). Jadi yang termasuk kategori HOTS adalah analisis, evaluasi dan kreasi. Menurut Ainin (2018), HOTS adalah tingkatan berpikir tinggi yang didalamnya berpikir kritis, analitis, logis, kreatif dan metakognitif. Menurutnya lagi bahwa kurikulum 2013 dalam pendidikan di Indonesia termasuk di dalamnya mata pelajaran bahasa Arab. (Jusman, 2018) 


\section{Arabi : Journal of Arabic Studies}

Berdasarkan peraturan menteri pendidikan dan kebudayaan nomor 67, 68, dan 69 tahun 2013 tentang kerangka dasar dan struktur kurikulum Sekolah Dasar sampai Sekolah Menengah Atas bahwa kurikulum 2013 menganut pola pikir: 1) yang menjadi sobjek pembelajaran adalah peserta didik, 2) Pembelajaran bersifat interaktif, 3) Sumber belajar bervariasi selain guru. Namun peserta didik juga dapat memperoleh informasi dari sumber lain, 4) Pembelajaran dapat mengaktifkan peserta didik, 5) Belajar berkelompok, 6) Pembelajaran menggunakan media, 7) Pembelajaran berbasis kebutuhan peserta didik dengan memperkuat pengembangan potensi mereka, 8) Materi pembelajaran terintegrasi dari berbagai ilmu pengetahuan, dan 9) Pembelajaran bersifat kritis.

Dari sembilan pola kurikulum 2013 di atas, dapat dipahami bahwa pembelajaran bahasa Arab juga menganut pola pembelajaran di atas. Artinya pembelajaran bahasa Arab juga menggunakan pola aktif, kreatif dan interaktif sehingga penguasaan materi lebih baik oleh para peserta didik. Maka, untuk dapat membelajarkan pola aktif, kreatif dan interaktif, guru sebaiknya menggunakan cara-cara yang menyenangkan bagi peserta didik dalam proses pembelajaran bahasa Arab. (Albantani, 2018) Dengan demikian, sumber kesulitan belajar bahasa Arab dari guru dan bahan ajar dapat diminimalisir. (Albantani dan Madkur, 2019)

Secara filosofis, kurikulum 2013 berlandaskan pada pengembangan kemampuan peserta didik baik bersifat pengetahuan, sikap maupun keterampilan dengan mengindahkan nilai-nilai keagamaan, sosial bangsa dan negara. Ditinjau dari aspek teoritis, dalam pengembangan kurikulum ini berdasarkan standar pendidikan dan berbasis kompetensi. Dari dua pandangan ini, dapat dipahami bahwa pembelajaran bahasa Arab diarahkan pada pendekatan komunikatif dan berbasis kompetensi yang dapat mengarahkan pembelajaran bahasa Arab kepada kemmapuan berkomunikasi sesuai konteks sosial bagi peserta didik.

Dalam kurikulum 2013 atau K 13 mengenal istilah kompetensi inti. Kompetensi inti atau disebut dengan KI ini terdiri dari 4, yaitu KI bermuatan nilai religius, KI bermuatan nilai sosial, KI 3 bermuatan nilai pengetahuan, dan KI 4 bermuatan nilai psikomotorik. Menurut Ainin (2018), Kompetensi inti, terutama KI 3 dan 4 direalisasikan dalam bentuk Kompetensi Dasar (KD).

\section{Sekilas Tentang KMA 183 Tahun 2019}

KMA yang digunakan sebelum KMA 183 tahun 2019 adalah KMA 165 tahun 2014. Dalam KMA ini, standar isi Bahasa Arab adalah: Bagaimana peserta didik dapat bersikap positif terhadap bahasa Arab dengan memiliki kemampuan memahami pembicaraan orang lain (reseptif) dan kemampuan menggunakannya dalam berkomunikasi (produktif). Adapun tujuannya ada dua, yaitu untuk dapat berkomunikasi dengan menggunakan bahasa Arab dan bahasa Arab sebagai alat dalam memahami teks-teks keagamaan Islam yang berbahasa Arab. (KMA 165 tahun 2014)

Adapun kemunculan KMA 183 tahun 2019 merupakan pengembangan kurikulum dari KMA sebelumnya. Dikatakan bahwa bahasa Arab memiliki tantangan yang cukup berat. Ada dua tantangan yang disebutkan dalam KMA ini, yaitu tantangan internal dan eksternal. Tantangan internal meliputi 1) arah pembelajaran bahasa Arab pada madrasah mengedepankan aspek kaidah kebahasaan dan kurang mengarah kepada aspek komunikasi, 2) bahasa Arab dipandang sebagai alat memahami ajaran Islam seperti Alquran dan hadis, 3) kurangnya penguasaan bahasa Arab sehingga menimbulkan kesalahpahaman terhadap penafsiran Alquran dan kurangnya minat belajar bahasa Arab karena mudahnya akses terhadap konten keislaman melalui media sosial. Maka untuk mengatasi tantangan internal tersebut diperlukan pengembangan kurikulum bahasa Arab yang memadukan antara penguasaan kaidah dan keterampilan; juga pembelajaran bahasa Arab mengarah pada penggunaannya dalam berkomunikasi sehingga peserta didik dapat memperoleh makna dalam setiap pembelajaran untuk dipraktikkan dalam keseharian tanpa mengeyampingkan budaya ke-Indonesiaan. (KMA 183 tahun 2019) menurut Jauhar (2007) suatu kurikulum mau tidak mau memerlukan arah baru yang sesuai dengan masanya terlebih dalam pembelajaran bahasa Arab.

Tantangan eksternal dalam pembelajaran bahasa Arab adalah 1) sebagai bahasa yang digunakan dalam hubungan internasional, 2) pengguna dan penutur bahasa Arab terus mengalami 
pertumbuhan seiring dengan berkembangnya hubungan internasional dengan negara-negara Arab diberbagai bidang dan 3) pesatnya perkembangan tekonologi yang menyebabkan masyarakat berpikir instan untuk memahami ajaran Islam. Maka untuk mengatasi tiga tantangan eksternal di atas diperlukan kurikulum dan materi pembelajaran bahasa Arab yang mengarah kepada pola Amiyah yang komunikatif-fungsional dan dapat memotivasi peserta didik untuk dapat mengkaji literatur-literatur berbahasa Arab. (KMA 183 tahun 2019)

Adanya pengembangan kurikulum bahasa Arab dari kurikulum 2013 ke 2019 yang menginginkan bahwa bahasa Arab harus difungsikan sebagai bahasa komunikasi internasional. Menurut Muradi (2014) memang seharusnya pembelajaran bahasa asing termasuk bahasa Arab diajarkan dalam rangka memenuhi berbagai siatuasi termasuk untuk komunikasi. Di tambahkan lagi oleh Jauhar (2015) bahwa arah yang dikehendaki suatu bahasa asing tersebut melalui pemahiran komunikasi berdasarkan budaya dan kebiasaan penutur aslinya. Maknanya adalah level KD bahasa Arab harus mengarah kepada HOTS.

KMA 183 tahun 2019 yang berkaitan dengan HOTS adalah melalui pembelajaran bahasa Arab dari dua tantangan di atas, bagaimana peserta didik dapat memiliki kemampuan dan keterampilan tingkat tinggi seperti memecahkan masalah, berpikir kritis, berpikir kreatif, memiliki kemampuan beragumen dan mengmbil keputusan. Inilah yang diamanahkan KMA ini bahwa semua jenis dan teknik penilaian harus diarahkan untuk mengukur pencapaian keterampilan berpikir tingkat tinggi/HOTS.

Untuk mengetahui jawaban atas problem di atas, penulis akan memaparkan hasil penelitian dan pembahasannya dalam sub judul berikutnya.

\section{Hasil Penelitian}

Dalam KMA 183 tahun 2019 terdapat tiga jenjang yaitu ibtidaiyah, tsanawiyah dan Aliyah. Jenjang Aliyah dibagi dalam dua kategori, kategori MA peminatan IPA, IPS, Bahasa dan Kejuruan dan MA Keagamaan. Adapun KD yang disajikan dan dianalisis adalah KD 3 dan KD 4 saja. Sebab KD 3 adalah ranah kognitif dan KD 4 adalah ranah psikomotorik.

KD Bahasa Arab MI

Tabel 1: KD 3 dan KD 4 Kelas 1-6 MI

\begin{tabular}{|c|c|}
\hline KD 3 & $\mathrm{KD} 4$ \\
\hline $\begin{array}{l}\text { Memahami pengetahuan faktual dengan } \\
\text { cara mengamati [mendengar, } \\
\text { melihat, membaca] dan menanya } \\
\text { berdasarkan rasa ingin tahu tentang } \\
\text { dirinya, makhluk ciptaan Tuhan dan } \\
\text { kegiatannya, dan benda-benda yang } \\
\text { dijumpainya di rumah dan di sekolah }\end{array}$ & $\begin{array}{l}\text { Menyajikan pengetahuan faktual } \\
\text { dalam bahasa yang jelas dan logis, } \\
\text { dalam karya yang estetis, dalam } \\
\text { gerakan yang mencerminkan anak } \\
\text { sehat, dan dalam tindakan yang } \\
\text { mencerminkan perilaku anak } \\
\text { beriman dan berakhlak mulia }\end{array}$ \\
\hline $\begin{array}{l}\text { 1. Memahami fungsi sosial dan unsur } \\
\text { kebahasaan (bunyi, kata dan makna) dari } \\
\text { teks sangat sederhana ... }\end{array}$ & $\begin{array}{l}\text { 1. Mendemonstrasikan tindak tutur } \\
\ldots\end{array}$ \\
\hline $\begin{array}{l}\text { 2. Menganalisis unsur kebahasaan (bunyi, } \\
\text { kata dan makna) dari teks sangat } \\
\text { sederhana ... }\end{array}$ & $\begin{array}{l}\text { 2. Menyajikan hasil analisis bunyi, } \\
\text { kata dan makna dari teks sangat } \\
\text { sederhana terkait tema: ... } \\
\text { dengan memperhatikan } \\
\text { kaidah penulisan huruf } \\
\text { hijaiyah }\end{array}$ \\
\hline
\end{tabular}

Dari sajian KD 3 dan KD 4 MI tersebut bahwa rincian KD 3 ada dua dan rincian KD 4 juga ada dua sebagaimana tabel 1 di atas. Sedangkan jumlah masing-masing KD adalah $10 \mathrm{KD}$. Pada 


\section{Arabi : Journal of Arabic Studies}

hakikatnya kedua KD tersebut sama untuk semua kelas MI dari kelas 1 sampai 6 (semester ganjil dan genap). Sementara yang membedakan adalah tema masing-masing kelas dan semester.

KD Bahasa Arab MTs

Tabel 2: KD 3 dan KD 4 kelas 7 - 9 MTs

KD 3

\begin{tabular}{|c|c|}
\hline $\begin{array}{l}\text { Memahami dan menerapkan pengetahuan } \\
\text { (faktual, konseptual, dan prosedural) } \\
\text { berdasarkan rasa ingin tahunya tentang } \\
\text { ilmu pengetahuan, teknologi, seni, budaya } \\
\text { terkait fenomena dan kejadian tampak } \\
\text { mata }\end{array}$ & $\begin{array}{l}\text { Mengolah, menyaji, dan menalar } \\
\text { dalamn ranah konkret (menggunakan, } \\
\text { mengurai, merangkai, memodifikasi, } \\
\text { dan membuat) dan ranah abstrak } \\
\text { (menulis, membaca, menghitung, } \\
\text { menggambar, dan mengarang) sesuai } \\
\text { dengan yang dipelajari di sekolah dan } \\
\text { sumber lain yang sama dalam sudut } \\
\text { pandang/ teori }\end{array}$ \\
\hline $\begin{array}{l}\text { 1. Memahami fungsi sosial, struktur teks } \\
\text { dan unsur kebahasaan (bunyi, kata, } \\
\text { makna dan gramatikal) dari teks } \\
\text { sederhana yang ... } \\
\text { yang melibatkan tindak tutur ... }\end{array}$ & $\begin{array}{l}\text { 1. Mendemonstrasikan tindak tutur ... } \\
\text { dengan menggunakan ... } \\
\text { baik secara lisan maupun tulisan. }\end{array}$ \\
\hline $\begin{array}{l}\text { 2. Menganalisis gagasan dari teks } \\
\text { sederhana yang ... } \\
\text {... dengan memperhatikan bentuk, } \\
\text { makna dan fungsi dari susunan } \\
\text { gramatikal ... }\end{array}$ & $\begin{array}{l}\text { 2. Menyajikan hasil analisis gagasan } \\
\text { dari teks sederhana yang berkaitan } \\
\text { dengan tema: ... } \\
\text { dengan memperhatikan bentuk, } \\
\text { makna dan fungsi dari susunan } \\
\text { gramatikal ... }\end{array}$ \\
\hline $\begin{array}{l}\text { 3. Menerapkan kaidah tentang bentuk, } \\
\text { makna dan fungsi gramatikal } \\
\text { dalam teks sederhana yang berkaitan } \\
\text {.. }\end{array}$ & $\begin{array}{l}\text { 3. Menyusun teks sederhana yang } \\
\text { berkaitan dengan tema: ... } \\
\text { dengan memperhatikan bentuk, } \\
\text { makna dan fungsi dari susunan } \\
\text { gramatikal ... }\end{array}$ \\
\hline
\end{tabular}

Dari sajian KD 3 dan KD 4 MTs tersebut bahwa rincian KD 3 ada tiga dan rincian KD 4 juga ada tiga sebagaimana tabel 2 di atas. Sedangkan jumlah masing-masing KD adalah $12 \mathrm{KD}$. Pada hakikatnya kedua KD tersebut sama untuk semua kelas MTs dari kelas 7 sampai 9 (semester ganjil dan genap). Sementara yang membedakan adalah tema masing-masing kelas, semester dan materi gramatikal.

KD Bahasa Arab MA Peminatan IPA, IPS, Bahasa dan Kejuruan Tabel 3: KD 3 dan KD 4 kelas 10 - 12 MA

\begin{tabular}{ll}
\hline \multicolumn{1}{c}{ KD 3 } & \multicolumn{1}{c}{ KD 4 } \\
\hline $\begin{array}{l}\text { Memahami, menerapkan, dan menganalisis } \\
\text { pengetahuan faktual, konsept ual, }\end{array}$ & $\begin{array}{l}\text { Mengolah, menalar, dan menyaji } \\
\text { dalam ranah konkret dan ranah }\end{array}$ \\
$\begin{array}{l}\text { prosedural, dan metakognitif berdasarkan } \\
\text { abstrak terkait dengan } \\
\text { pengetahuan, teknologi, seni, budaya, dan } \\
\text { humaniora dengan wawasan kemanusiaan, } \\
\text { kebangsaan, kenegaraan, dan peradaban } \\
\text { derkait penyebab fenomena dan kejadian, }\end{array}$ & $\begin{array}{l}\text { mandiri, dan man di sekolah secara } \\
\text { metode sesuai kaidah keilmuan }\end{array}$ \\
$\begin{array}{l}\text { serta menerapkan pengetahuan prosedural } \\
\text { pada bidang kajian yang spesifik sesuai } \\
\text { dengan bakat dan minatnya untuk }\end{array}$ & \\
\hline
\end{tabular}


memecahkan masalah

1. Memahami fungsi sosial, struktur teks, 1. Mendemonstrasikan tindak tutur dan unsur kebahasaan (bunyi, kata, dan makna) dari teks yang ... yang melibatkan tindak tut ur ... mengenalkan diri dan orang lain, meminta maaf, berpamitan dengan Memperhatikan ... baik secara lisan maupun tulisan.

2. Menganalisis gagasan dari teks bahasa 2. Menyajikan hasil analisis gagasan Arab yang berkaitan ... dengan memperhatikan bentuk, makna dan fungsi dari ... dari teks bahasa Arab yang berkaitan dengan tema ... dengan memperhatikan bentuk, makna dan fungsi dari ...

3. Menerapkan kaidah tentang bentuk, 3. Menyusun teks bahasa Arab yang makna dan fungsi dari susunan gramatikal ...

Menyusun teks bahasa Arab yang berkaitan ...

berkaitan dengan tema ...

dalam menyusun teks bahasa

Arab yang berkaitan dengan tema: ...

dalam menyusun teks bahasa Arab yang berkaitan dengan tema :

dengan memperhatikan bentuk, makna dan fungsi dari susunan gramatikal ...

baik secara lisan maupun tulisan.

4. Mengevaluasi teks bahasa Arab yang 4. Menyajikan hasil evaluasi teks berkaitan ...

bahasa Arab yang berkaitan

dengan memperhatikan bentuk, makna dan fungsi dari susunan gramatikal

dengan tema ...

dengan memperhatikan bentuk, makna dan fungsi dari susunan gramatikal ...

baik secara lisan maupun tulisan.

Dari sajian KD 3 dan KD 4 MA peminatan IPA, IPS, Bahasa dan Kejuruan tersebut bahwa rincian KD 3 ada empat dan rincian KD 4 juga ada empat sebagaimana tabel 3 di atas. Sedangkan jumlah masing-masing KD adalah $12 \mathrm{KD}$. Pada hakikatnya kedua KD tersebut sama untuk semua kelas MA dari kelas 10 sampai 12 (semester ganjil dan genap). Sementara yang membedakan adalah tema masing-masing kelas, semester dan materi gramatikal.

KD Bahasa Arab MA Keagamaan

Tabel 4: KD 3 dan KD 4 kelas 10 - 12 MAK

KD 3

Memahami, menerapkan, dan menganalisis

pengetahuan faktual, konseptual,

prosedural, dan metakognitif berdasarkan

rasa ingin tahunya tentang ilmu

pengetahuan, teknologi, seni, budaya, dan

humaniora dengan wawasan kemanusiaan,

kebangsaan, kenegaraan, dan peradaban

terkait penyebab fenomena dan kejadian,

serta menerapkan pengetahuan prosedural

pada bidang kajian yang spesifik sesuai

dengan bakat dan minatnya untuk

memecahkan masalah

1. Menganalisis bentuk, makna dan fungsi 1. Menyajikan hasil analisis bentuk, dari susunan gramatikal ...

$\mathrm{KD} 4$

Mengolah, menalar, dan menyaji

dalam ranah konkret dan ranah

abstrak terkait dengan

pengembangan dari yang

dipelajarinya di sekolah secara

mandiri, dan mampu menggunakan

metode sesuai kaidah keilmuan makna dan fungsi dari susunan 
gramatikal ... dalam kalimat sesuai dengan konteks ... dalam sebuah wacana sesuai konteks.

Dari sajian KD 3 dan KD 4 MA peminatan Keagamaan tersebut bahwa rincian KD 3 ada satu dan rincian KD 4 juga ada satu sebagaimana tabel 4 di atas. Sedangkan jumlah masing-masing KD dari kelas 10-12 adalah 8 KD. Sementara KD kelas 12 hanya 7 KD. Pada hakikatnya KD tersebut sama untuk semua kelas MAK dari kelas 10 sampai 12 (semester ganjil dan genap). Sementara yang membedakan adalah tema masing-masing kelas, semester dan materi gramatikal plus dari semester genap kelas 11 sampai kelas 12 terdapat materi balaghah.

\section{Pembahasan}

Sebagaimana telah disebutkan dalam KMA 183 tahun 2019 halaman 70 bahwa arah penilaiannya kepada HOTS. Sementara menurut Ainin (2018) bahwa HOTS dalam pembelajaran bahasa Arab dapat dilakukan terhadap sekolah tertentu yang lingkungan berbahasa Arabnya kondusif. Namun menurut penulis, dari sebagian KD yang terdapat dalam KMA 183 tahun 2019 sudah mencerminkan atau mengarahkan pembelajaran kepada HOTS. Meskipun demikian sebagian KD lainnya mengarahkan kepada pembelajaran Lower Order Thinking Skills (LOTS) dan Middle Order Thinking Skills (MOTS).

Terkait taksonomi Bloom ranah kognitif, apektif dan psikomotorik pada KMA 183 tahun 2019 bisa dikatakan aspek apektif lebih dominan dari dua ranah lainnya. Menurut Rohman (2018), apektif adalah sikap dan perilaku dari pserta didik yang merupakan hasil pendidikan baik di dalam kelas maupun diluar kelas.

Ranah apektif dalam KMA tersebut dibagi menjadi dua aspek yaitu religious dan sosial. Bahkan menurut Ainin dan Asrori (2019), pengekplisitan ranah apektif religious dan apektif sosial merupakan ciri khas kurikulum 2013. Menurut Raswan (2018) semua proses pendidikan mengarah kepada tiga ranah pendidikan yang dengannya merupakan hasil belajar. Jadi semua pembelajaran bahasa di semua jenjang mengarah kepada tiga ranah tersebut yang tercermin dalam kompetensi dasar (KD).

Di sini penulis berikan analisis terhadap KD yang telah disebutkan dalam sub tema sebelumnya.

\section{a. Jenjang MI}

Berdasarkan jenjang madrasah, MI misalnya dapat dikatakan mengarah kepada LOTS meskipun di dalam KDnya terdapat kata 'analisis'.

Pada KD 3.1 ini sudah jelas bahwa tujuan pembelajaran bahasa Arab jenjang MI adalah memahami yaitu $\mathrm{C} 2$ yang termasuk dalam kategori LOTS.

Pada KD 3.2 terdapat kata 'menganalisis' yang meskipun masuk dalam kategori HOTS namun untuk jenjang MI yang dimaksud dengan 'menganalisis' adalah dalam kategori analisis sederhana. Yakni yang dianalisis adalah unsur bunyi, perbedaan bunyi dan pengucapan huruf hijaiyah. Sebab perbedaan huruf akan menghasilkan bunyi yang berbeda dan sementara bunyi yang berbeda akan menghasilkan makna dan terjemah yang berbeda pula.

Demikian pula pada KD 4.2 ini adalah hasil perbedaan huruf yang menghasilkan bunyi yang berbeda dan makna yang berbeda pula sehingga para peserta didik jenjang MI dapat memahami perbedaan tersebut. Menururt alBantani (2018) arah yang dominan dalam pembelajaran bahasa Arab pada jenjang madrasah ibtidaiyyah adalah keterampilan menyimak dan berbicara dalam lingkup yang masih sederhana.

\section{b. Jenjang MTs}

Dari KD 3.1 dapat diketahui bahwa peserta didik diharapkan 'memahami' materi berupa penggunaan bahasa baik dari segi struktur teks maupun segi unsur kebahasaan dalam teks 
sederhana. Pemahaman ini menjadi dasar kemampuan untuk menggunakannya dalam komunikasi. Pemahaman di sini masuk dalam kategori $\mathrm{C} 1$.

Pada KD 3.2 mengarahkan kegiatan pembelajaran kepada analisis teks sederhana dari aspek gagasan yang terkandung di dalamnya sesuai dengan tema dan unsur kebahasaan yang muncul dalam teks tersebut berupa bentuk kata, makna dan strukturnya. Di sini peserta didik diharapkan mampu menganalisisnya dengan baik. Kegiatan pembelajaran dan arahnya dapat dikategorikan C4 namun masih dalam level MOTS. Sebab teks yang dikaji masih teks sederhana. Meskipun dalam menganalisis terdapat proses berpikir kritis untuk menghasilkan hasil analisis yang beralasan. (R. Collin, 2014)

Adapun KD 3.3 merupakan penerapan dari hasil analisis sederhana yang dilakukan peserta didik terhadap teks sederhana sesuai dnegan tema, unsur kebahasaan dan strukturnya. Hal ini pun masuk dalam kategori C3 dan level MOTS.

Sebagaimana diketahui bahwa KD 4 merupakan ranah psikomotorik. Namun demikian kemampuan peserta didik dalam KD 4 ini sangat dipengaruhi oleh KD 3 ranah kognitif. Artinya sejauhmana kemampuan peserta didik dalam menyerap materi secara kognitif akan berpengaruh baik atau tidak baik terhadap kemampuannya dalam psikomotorik. Karena itu, mendemonstrasikan, menyajikan hasil analisis dan menyusun teks sederhana adalah ranah psikomotorik yang sangat ditentukan oleh kemampuan kognitif peserta didik dalam penerapannya. Penerapan masuk dalam kategori C3 dan level MOTS. Dan dalam buku Penilaian Berorientasi HOTS bahwa penerapan termasuk level 2 dalam kognitif dan bukan termasuk HOTS. (Direkto

\section{c. Jenjang MA Peminatan IPA, IPS, Bahasa dan Kejuruan}

Sama seperti analisis sebelumnya pada jenjang MTs bahwa kata memahami dalam KD 3.1 tersebut masih dalam kategori $\mathrm{C} 2$ atau level di bawah HOTS. Karena jenjang ini adalah jenjang MA maka bisa dikatakan C2 ini masuk dalam level MOTS atau berpikir tingkat menengah.

Pada KD 3.2, para peserta didik sudah diarahkan kepada C4 yaitu menganalisis. Bahkan teks bahasa Arab yang dianalisis tidak lagi teks sederhana serta struktur gramatika kebahasaan yang kompleks. Juga dapat dikatakan bahwa pada KD ini peserta didik diberikan soal-soal sebagai bentuk permasalahan yang nantinya mereka pecahkan masalah tersebut. Jadi dapat dikatakan bahwa KD 3 dengan redaksi menganalisis gagasan sudah masuk ke level HOTS. Bahkan tahap analisis merupakan bagian dari pemahaman bacaan yang dibagi dalam lima taksonomik pada tingkat kedua, yaitu reorganisasi di mana di dalamnya adalah analisis. (Ampuni, 1998)

Adapun KD 3.3 merupakan KD yang mengarahkan peserta didik untuk dapat mengaplikasikan pemahaman dan hasil analisis mereka terhadap materi yang telah dipelajari. Maka harapannya adalah mereka dapat menerapkannya sesuai dengan standar-standar keterampilan berbahasa yang baik dan benar; sesuai dengan tema dan struktur gramatika. Jadi KD ini masuk dalam level C3 (menerapkan).

3.4: Mengevaluasi teks bahasa Arab yang berkaitan dengan ... dengan memperhatikan bentuk, makna dan fungsi dari susunan gramatikal...

KD 3.4 adalah mengevaluasi. Evaluasi merupakan C5 dari ranah kognitif. Artinya peserta didik dapat menilai dan mengkritik terhadap materi bahasa Arab yang dipelajari. Sebenarnya dalam proses membaca terdapat evaluasi atau penilaian dari guru dalam suatu pembelajaran. Sebagaimana disebutkan Ampuni (1998) bahwa evaluasi adalah tingkat keempat dari lima taksonomik pemahaman bacaan. Pada tingkat evaluasi ini, pembaca memberikan penilaianpenilaian tentang teks yang dibaca apakah realita atau fantasi; teks berupa fakta atau opini; apakah teks memiliki informasi baru atau tidak; apakah teks sesuai dengan cerita dan karakter tokohnya; apakah perbuatan tokoh benar atau salah; dan apakah pembaca sependapat dengan penulis teks. Jadi KD ini dapat dikategorikan HOTS.

Sementara KD 4, yaitu KD 4.1, 4.2, 4.3, dan 4.4 Sama seperti analisis terhadap KD 4 jenjang MTs bahwa KD 4 adalah masuk kategori MOTS dan bukan HOTS yaitu KD 4 adalah penerapan. 


\section{Arabi : Journal of Arabic Studies}

\section{d. Jenjang MA Keagamaan}

Persis seperti jenjang MA peminatan IPA, IPS, Bahasa dan Kejuruan bahwa KD 3 jenjang MA keagamaan ini mengarahkan peserta didik kepada kegiatan $\mathrm{C} 4$ analisis yaitu memecahkan bahan/konsep ke dalam aspek-aspek kecip yang kemudian dihubungkan dalam satu hubungan yang saling terkait. Misalnya analisis gramatika tentang muzakkar dan mu'annats. (KMA 183 tahun 2019). Dalam pembagian kata dari aspek jenis kelamin. Pembagian ini penting diketahui karena berkaitan dengan susunan gramatika dalam kalimat. Misalnya kalimat isim yang mengharuskan adanya kesesuaian muzakkar dan mu'annats antara sobjek dan predikat. Demikian juga dalam kaidah struktur lain. Bahkan pada kelas XII di antara materi bahasa Arab adalah balaghah. Misalnya tentang tasybih, isti'arah, kinayah dan lainnya. Jadi dapat dikatakan bahwa KD 3 ini termasuk level HOTS dalam ranah kognitif.

Persis seperti yang telah disampaikan dalam analisis KD 4 pada jenjang MA peminatan di atas bahwa KD 4 ini termasuk ranah psikomotorik. Namun KD ini sangat berkaitan dengan penguasaan ranah kognitif pada KD 3. Maka penguasaan KD 4 sangat dipengaruhi oleh penguasaan terhadap KD 3. Sebagaimana pandangan Faruq dan Huda (2020) bahwa inti HOTS ialah pengembangan kompetensi peserta didik dalam memecahkan masalah melewati suatu problem dengan menggunakan perspektif baru berdasarkan pengetahuan sebelumnya. Demikian pula halnya dengan pembelajaran bahasa Arab, pemahiran ranah kognitif dan psikomotorik merupakan pemberian pengetahuan sekaligus pengalaman sesuai dengan masanya atau suasana yang mengitari peserta didik. Maka, lebih mudah bagi peserta didik menguasai bahasa Arab dan memparaktikkannya dalam berbagai kesempatan.

\section{Simpulan}

Sebagai penutup artikel ini dapat penulis simpulkan bahwa sebagian KD dalam KMA 183 tahun 2019 termasuk Lower Order Thinking Skills, Middle Order Thinking Skills dan Higher Order Thinking Skills. KD pada jenjang MI semuanya kategori LOTS, sedangkan KD jenjang MTs sebagian besar masuk kategori LOTS dan sebagian Kecil masuk kategori MOTS. Sementara KD MA peminatan IPA, IPS, Bahasa dan Kejuruan satu KD yaitu memahami masuk dalam kategori MOTS dan KD menganalisis dan mengevaluasi termasuk kategori HOTS. Sedangkan jenjang MA Keagamaan dengan hanya satu KD yaitu menganalisis termasuk kategori HOTS. Sementara level C6 mengkreasi tidak ditemukan. Jadi dapat dikatakan bahwa kompetensi dasar bahasa Arab dalam KMA 183 tahun 2019 belum mengarahkan HOTS pada tingkat MI dan MTs. Sedang pada tingkat MA, aspek HOTS yang telah dimuat adalah adalah kemampuan berpikir tingkat tinggi berupa problem solving, critical thinking, dan reasoning. Adapun KD level HOTS dalam KMA tersebut tidak mencapai creative thinking dan decision making. Melalui simpulan ini dapat penulis sarankan bahwa hendaknya muatan HOTS dalam KD bahasa Arab pada jenjang MA perlu ditambahkan dan pada jenjang MI dan MTs juga ditambahkan muatan LOTS dan MOTS.[]

\section{Daftar Rujukan}

Abdullah, A. H., Abidin, N. L. Z., \& Ali, M. 2015. “Analysis of students' errors in solving Higher Order Thinking Skills (HOTS) problems for the topic of fraction", Asian Social Science, Vol. 11, No. 21.

Ainin, M. 2018. "Penilaian dalam Pembelajaran Bahasa Arab di Madrasah atau Sekolah: HOTS, MOTS atau LOTS?", Prosiding Konfererensi Nasional Bahasa Arab, Vol. 4, No. 4.

Ainin, M., \& Asrori, I. 2020. "Ketaksaan silabus mata pelajaran bahasa Arab tahun 2016 untuk jenjang menengah atas", Arabi: Journal of Arabic Studies, Vol. 4, No. 2.

Albantani, A. M., \& Madkur, A. 2019. "Teaching Arabic in the era of Industrial Revolution 4.0 in Indonesia: Challenges and opportunities", ASEAN Journal of Community Engagement, Vol. 3, No. 2. 
Albantani, A. M. 2018. "Pembelajaran bahasa Arab di Madrasah Ibtidaiyah: sebuah ide terobosan", Attadib: Journal of Elementary Education, Vol. 2, No. 2.

Albantani, A. M. 2018. "Arabic language learning strategies for early-aged children: language recognition and motivation building", Prosiding Pertemuan Ilmiah Internasional Bahasa Arab.

Albantani, A. M. 2015. "Implementasi kurikulum 2013 pada pembelajaran bahasa Arab di madrasah ibtidaiyah", Arabiyat: Jurnal Pendidikan Bahasa Arab dan Kebahasaaraban, Vol. 2, No. 2.

Alsowat, H. 2016. "An EFL flipped classroom teaching model: Effects on English language higher-order thinking skills, student engagement and satisfaction", Journal of Education and Practice, Vol. 7, No. 9.

Ampuni, S. 1998. "Proses Kognitif dalam pemahaman bacaan”, Buletin Psikologi, Vol. 6, No. 2.

Awaliyah, Gumanti. "Kemendikbud Akui Banyak Guru Salah Persepsi Terkait HOTS", https://www.republika.co.id/ accessed January 17, 2020.

Chinedu, C. C., Olabiyi, O. S., \& Kamin, Y. 2015. "Strategies for improving higher order thinking skills in teaching and learning of design and technology education", Journal of Technical Education and Training, Vol. 7, No. 2.

Collins, R. 2014. "Skills for the 21st Century: teaching higher-order thinking", Curriculum \& Leadership Journal, Vol. 12, No. 14.

Fanani, M. Z. 2018. "Strategi pengembangan soal hots pada kurikulum 2013”, Edudeena: Journal of Islamic Religious Education, Vol. 2, No. 1.

Faruq, U., \& Huda, M. M. 2020. "Bahasa Arab Berbasis Peningkatan Pembelajaran HOTS (Higher Order Thinking Skills) (Kajian Pembelajaran Bahasa Arab Di Madrasah Aliyah Unggulan Darul 'Ulum Step 2 Kemenag RI)”, Al-Hikmah: Jurnal Kependidikan dan Syariah, Vol. 8, No. 1.

Hayikaleng, N., Nair, S. M., \& Krishnasamy, H. N. 2016. “Thai students' L2 reading comprehension level for lower order thinking skills and higher order thinking skills questions", Journal of Applied Linguistics and Language Research, Vol. 3, No. 5.

Heong, Y. M., Othman, W.D., Md Yunos, J., Kiong, T.T., Hassan, R., \& Mohamad, M.M. 2011. "The Level of Marzano Higher Order Thinking Skills among Technical Education Students", International Journal of Social and humanity, Vol. 1, No. 2.

Herman, T. 2007. "Pembelajaran Berbasis Masalah Untuk Meningkatkan Kemampuan Berpikir Matematis Tingkat Tinggi Siswa Sekolah Menengah Pertama”, Jurnal Educationist, Vol. 1, No. 1.

Hugerat, M., \& Kortam, N. 2014. "Improving higher order thinking skills among freshmen by teaching science through inquiry", Eurasia Journal of Mathematics, Science \& Technology Education, Vol. 10, No. 5.

Jauhar, N. I. 2015. "Ta'lim Al-Lughah 'Abr Al-Tsaqafat wa Tathbiquhu Fi Ta'lim Al-Lughah Al'Arabiyah Fi Indonesia", Arabiyât: Jurnal Pendidikan Bahasa Arab dan Kebahasaaraban, Vol. 2, No. 2

Jauhar, N. I. 2007. "Ittihajahat Jadidah fi Majal Ta'lim al-Lugah al-Arabiyyah fi Indonesia", Journal of Indonesian Islam, Vol. 2, No. 1.

Jusman, M. J. M. 2018. "Pengaruh Kemampuan Penalaran Formal, Motivasi Berprestasi, dan Kesadaran Metakognitif terhadap Prestasi Belajar Matematika Siswa Kelas XI IPA SMA Negeri di Kota Parepare”, Disertasi, Universitas Negeri Makassar. 


\section{Arabi : Journal of Arabic Studies}

Kartono, K., \& Rusilowati, A. 2019. "Development of Assessment Instruments Mathematic Creative Thinking Ability on Junior High School Students", Journal of Research and Educational Research Evaluation, Vol. 8, No. 1.

KMA 165 tahun 2014 Tentang Kurikulum PAI dan Bahasa Arab pada Madrasah.

KMA 183 tahun 2019 Tentang Kurikulum PAI dan Bahasa Arab pada Madrasah.

Krathwohl, D.R. \& Anderson, L.W. 2001. A Taxonomy for Learning, Teaching, And Assesing; A Revision of Bloom's Taxonomy Of Education Objective. New York: Addoson Weslay Longman Inc.

Margana, M., \& Widyantoro, A. (2017). Developing English textbooks oriented to higher order thinking skills for students of vocational high schools in Yogyakarta. Journal of Language Teaching and Research, 8(1).

Moleong, Lexy J. 2010. Metodologi Penelitian Kualitatif. Bandung: Remaja Rosdakarya.

Muradi, A. 2016. "Pengembangan Kompetensi Guru Bahasa Arab Melalui IMLA Sebagai Organisasi Profesi", Arabi: Journal of Arabic Studies, Vol. 1, No. 2.

Muradi, A. 2014. "Pendekatan komunikatif dalam pembelajaran bahasa Arab", Arabiyat: Jurnal Pendidikan Bahasa Arab dan Kebahasaaraban, Vol. 1, No. 1.

Mustain, M. A. 2019. "Pembelajaran Bahasa Arab Berbasis Higher Order Thinking Skills (HOTS)", paper presented at Seminar Nasional Bahasa Arab Mahasiswa III.

OECD. 2019. "Programme for International Student Assessment (PISA) Result from PISA 2018", https://www.oecd.org/pisa/publications/PISA2018_CN_IDN.pdf accessed December 27, 2019.

Rahmawati, N. 2018. "Pembelajaran Bahasa Arab: Menuju Higher Order Thinking Skills (HOTS)", Prosiding Konfererensi Nasional Bahasa Arab, Vol. 4, No. 4.

Raswan, R. 2018. "Pengaruh Metode Pembelajaran Eklektik Terhadap Hasil Belajar Bahasa Arab Siswa", Arabiyat: Jurnal Pendidikan Bahasa Arab dan Kebahasaaraban, Vol. 5, No. 1.

Rohman, M. 2018. "Pembelajaran Bahasa Arab di Madrasah Aliyah dalam Perspektif Kurikulum 2013”, An Nabighoh: Jurnal Pendidikan dan Pembelajaran Bahasa Arab, Vol. 20, No. 2.

Saido, G. M., Siraj, S., Nordin, A. B. B., \& Al_Amedy, O. S. 2018. "Higher order thinking skills among secondary school students in science learning", MOJES: Malaysian Online Journal of Educational Sciences, Vol. 3, No. 3.

Salahuddin, M., \& Asroriyah, F. 2019. "Kecakapan Berpikir Dalam Konteks Pendekatan Pembelajaran Pada Kurikulum Sekolah Di Indonesia", Al-Adabiya: Jurnal Kebudayaan dan Keagamaan, Vol. 14, No. 1.

Sugiyono. 2016. Metode Penelitian Kuantitatif, Kualitatif, dan R\&D. Bandung: Alfabeta.

Tim Penulis. 2019. Buku Penilaian Berorientasi Higher Order Thinking Skills. Jakarta: Direktorat Jenderal Guru dan Tenaga Kependidikan Kementerian Pendidikan dan Kebudayaan RI.

Wilson, L. O. 2016. “Anderson and Krathwohl-Bloom's taxonomy revised: Understanding the New Version of Bloom's Taxonomy", https:/quincycollege.edu/content/uploads/Andersonand-Krathwohl_Revised-Blooms-Taxonomy.pdf accessed December 27, 2019.

Yaniawati, R. P. 2013. "E-learning to improve higher order thinking skills (HOTS) of students", Journal of Education and Learning, Vol. 7, No. 2. 